\title{
Notes on Scythrididae of Central Asia, with description of a new species (Lepidoptera: Scythrididae)
}

\author{
Kari Nupponen, Timo Nupponen, Risto Haverinen \& Aleksander Pototski
}

\begin{abstract}
Nupponen, K., Nupponen, T., Haverinen, R. \& Pototski, A. 2016: Notes on Scythrididae of Central Asia, with description of a new species (Lepidoptera: Scythrididae). - Entomol. Fennica 27: 118-132.

Scythris innae K. Nupponen \& Haverinen, sp. n. is described from SE Kazakhstan. The genitalia of previously unknown females of Falkovitshella hindukushi Passerin d'Entrèves \& Roggero, 2013, F. hypolepta (Falkovitsh, 1972) and S. niemineni Nupponen, 2014 are described. Records of 26 species embracing 304 specimens of the family Scythrididae from Kazakhstan and Tajikistan are presented. The material was collected during 2013-2014 in the course of four Finnish-Russian and Finnish-Estonian expeditions. Four species are reported as new to Kazakhstan and eight species as new to Tajikistan. The known distribution range of each species is given, and the taxonomy of some species is briefly discussed.
\end{abstract}

K. Nupponen, Merenneidontie 19 D, FI-02320 Espoo, Finland; e-mail: Kari.Nupponen@kolumbus.fi

T. Nupponen, Staffanintie 10 A, FI-02360 Espoo, Finland; e-mail: Timo.Nupponen@capgemini.com

R. Haverinen, Kolmikoivuntie 1 C, FI-01680 Vantaa, Finland; e-mail: R.Haverinen@luukku.com

A. Pototski, Uuslinna 5-1, EE-11413 Tallinn, Estonia; e-mail: Aleksander.Pototski@gmail.com

Received 16 April 2015, accepted 14 January 2016

\section{Introduction}

The present article is based on new materials of Scythrididae collected during 2013-2014 in the course of four Finnish-Russian and Finnish-Estonian expeditions to Kazakhstan and Tajikistan. The aim of the trips was to investigate scythridids in two specific aspects: the early spring fauna at lowlands, and the high altitude fauna of the Pamir Mountains, both of which are almost completely unknown.

\section{Materials and methods}

The Finnish-Russian expedition to southern and western Kazakhstan was made during 9.IV.6.V.2014. The investigated area covered the Emba River basin, the Mugodzhary mountain range, the Barsuki desert, north shore of the Aral Sea, the Syr-Darya valley eastwards to Turkestan, the Karatau Mountains and the Muyunkum desert.

Three Finnish-Estonian expeditions to Central Asia were carried out as follows: south- 
Fig. 1. Adult male of Scythris innae K. Nupponen \& Haverinen, sp. n. (holotype; SE Kazakhstan).

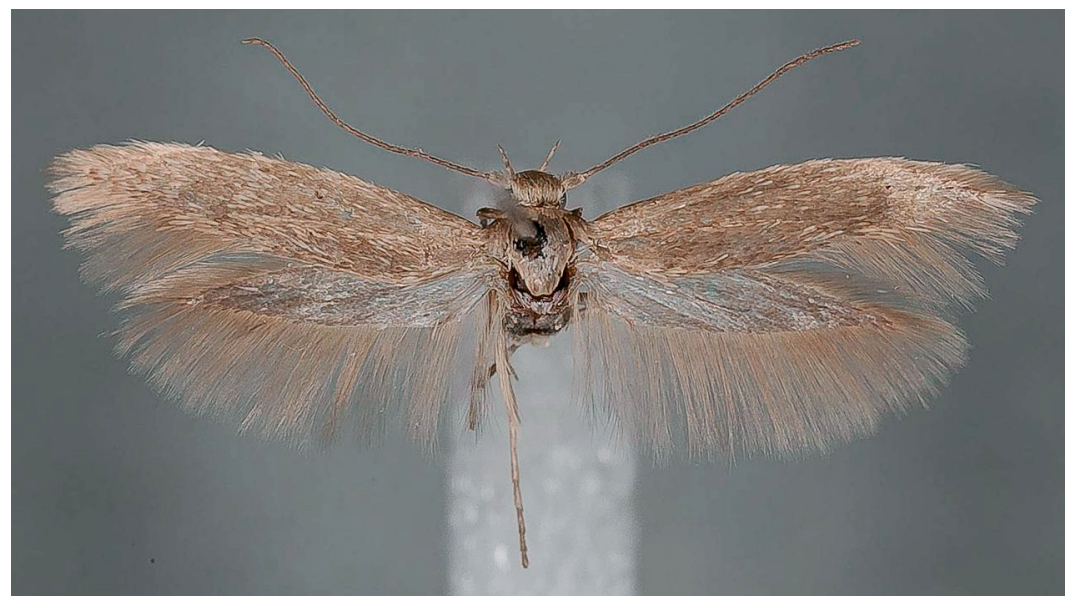

eastern Kazakhstan during 30.V.-8.VI.2014, and Tajikistan during 15.-30.VII.2013 and 1.6.V.2014. The first Tajikistan trip directed to the high altitudes (up to 4,700 $\mathrm{m}$ a.s.1.) of $\mathrm{C}$ and $\mathrm{E}$ Pamir Mountains, and the second one to the Tugai forest by riversides and adjacent foothills in the SW corner of the country. In early June 2014, we explored the Charyn Canyon and Ili River basin in SE Kazakhstan.

Altogether 26 species embracing 304 specimens of scythridids were recorded during the trips. The material was collected by light trapping at night and netting during daytime. Tissue samples (dried legs) of few specimens were shipped to the Canadian Centre for DNA Barcoding in Guelph for DNA sequence analysis. The barcodes are preserved in the Barcode of Life Data Systems (BOLD; see http://v4.boldsystems. org), and were used to calculate genetic distances reported below.

\section{Descriptions}

\subsection{Description of Scythris innae K. Nupponen \& Haverinen, sp. $\mathbf{n}$.}

Scythris innae K. Nupponen \& Haverinen, sp.n.

Type material. Holotype (ठ): Kazakhstan, $43^{\circ} 14^{\prime} 36^{\prime \prime} \mathrm{N} 78^{\circ} 52^{\prime} 48^{\prime \prime}$ E, 1,220 m, Charyn River, 1.VI.2014, K. Nupponen \& R. Haverinen leg. Genitalia slide: K. Nupponen prep. no. 1/24.VIII.2014. DNA sample (Lepid. Phyl., green label): KN00494. In coll. T. \& K. Nupponen.
Diagnosis. Externally S. innae K. Nupponen \& Haverinen, sp. n. is easily confused with several pale and unicoloured species, e.g. S. caroxylella Falkovitsh,1969, small specimens of $S$. niemineni K. Nupponen, 2014, and some forms of $S$. canescens (Staudinger, 1880). Examination of the genitalia is required for confident determination. The male genitalia of $S$. innae sp. n. are easily separated from those of related species in the pascuella species-group by the very large uncus, the robust phallus, and claviform valvae with pointed tip.

Description (Fig. 1). Wingspan $11.5 \mathrm{~mm}$. Head, collar, neck tuft and thorax sand coloured, collar slightly paler than thorax. Haustellum cream. Scape sand coloured; ventral hairscales paler. Flagellum brown, $0.75 \times$ length of forewing. Labial palp: segment I and lower surface of II cream, upper surface of II and III pale sand coloured. Legs: femur dirty white, tibia and tarsus sand coloured, tibia paler than tarsus; hindleg tibia covered by long hairscales. Abdomen dorsally fuscous; ventral side basally fuscous, segments IV-VIII dirty white. Forewing sand coloured, pattern absent. Hindwing pale fuscous.

Male genitalia (Figs. 2-3). Uncus large, bilobed, lobes semicircular and fused at basal third (mounted ventrally in Fig. 2). Gnathos base belt-like with parallel posterior bulges; proximal arm shorter than uncus, basally broad, tapered to $2 / 3$, distal $1 / 3$ thin, tip slightly swollen, bent downward and pointed. Phallus as long as valva, thick, slightly meandering, tip blunt. Valva claviform; basal half of even width; at 0.5 broad- 


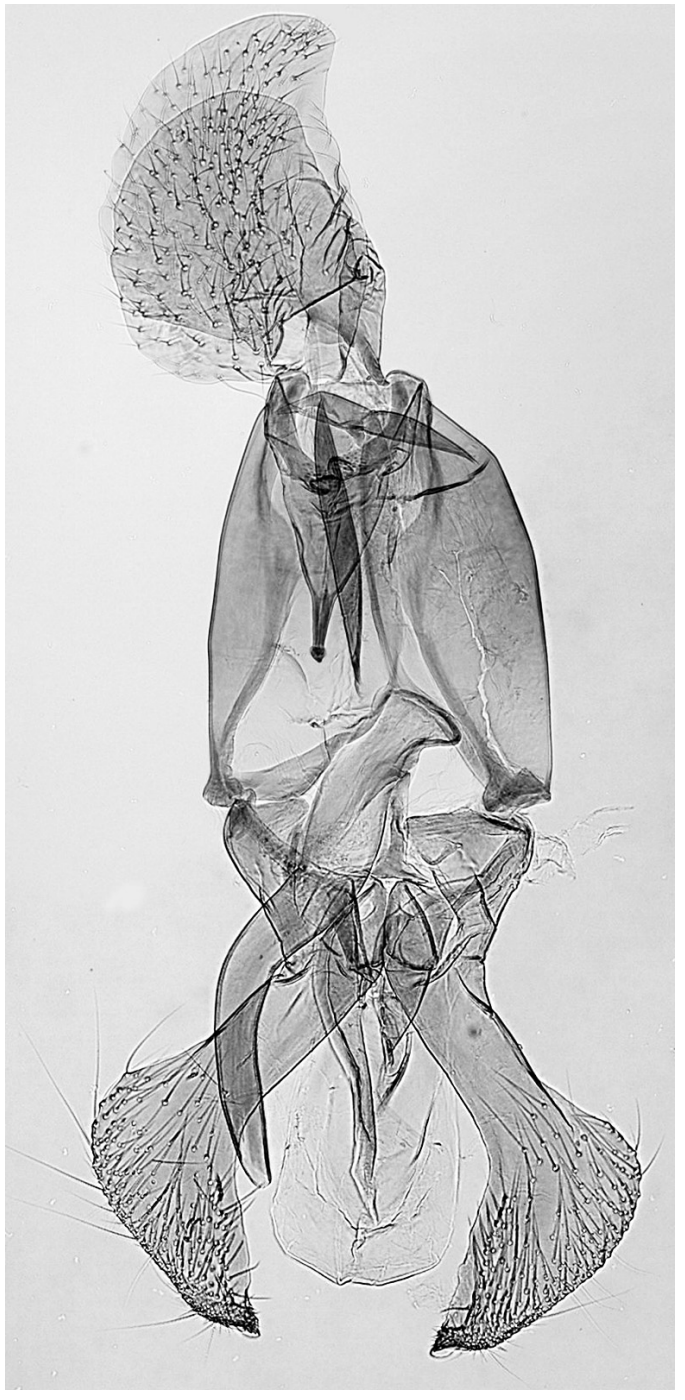

Fig. 2. Male genitalia of Scythris innae K. Nupponen \& Haverinen, sp. n. (holotype; Genitalia slide: 1/24.VIII. 2014 KN).

ened and bent 70 degrees inward; distally tapered, tip pointed; small apical flap at outer surface. Vinculum rectangular, 3/4 length of valva. Sternum VIII subpentagonal, posteriorly elongated and bifurcate, prongs robust with more or less pointed tip; anterior margin concave. Tergum VIII subtrapezoid, posteriorly widely concave, posterior corners elongated, blunt and diverging; anterior margin concave and somewhat reinforced.

Female genitalia. Unknown.

Bionomy. The specimen came to light at

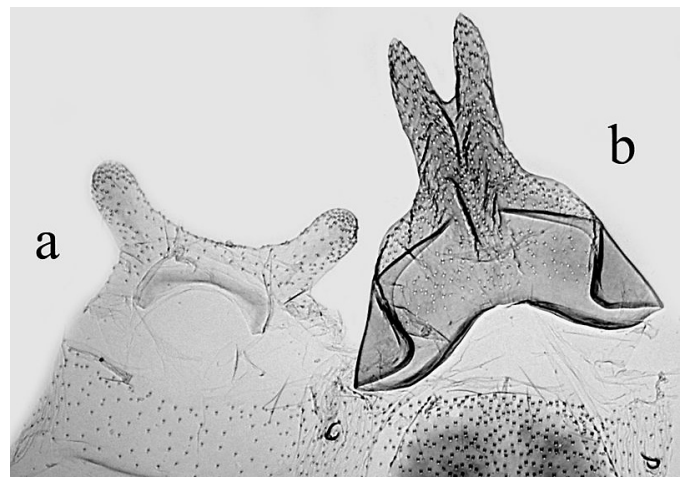

Fig. 3. Abdominal segment VIII) of Scythris innae K. Nupponen \& Haverinen, sp. n. - a. Tergum. - b. Sternum. (holotype; Genitalia slide: 1/24.VIII.2014 KN).

night. The habitat is a steep river canyon with rocky steppe slopes on both sides (Fig. 4).

Distribution. SE Kazakhstan.

Etymology. The species is named after Inna Antikainen, daughter of Risto Haverinen.

Remarks. Scythris innae K. Nupponen \& Haverinen, sp. $\mathbf{n}$. is placed in the heterogeneous pascuella species-group. Based on the DNA barcodes, the new species is related to the taxa in the $S$. caroxylella complex.

\subsection{Species with descriptions of females}

Falkovitshella hindukushi Passerin d'Entrèves \& Roggero, 2013

Material. Tajikistan, W Pamir Mts., $38^{\circ} 18^{\prime}$ 26" N 72 28' 38” E, 2,770 m, Murghab River Valley, by Barchadev village, 4 추 3 우 19.VII.2013, K. Nupponen \& R. Haverinen leg. Genitalia slides: K. Nupponen prep. no.

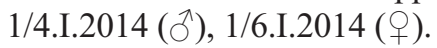

Female genitalia (Figs. 5-6). Sterigma long and straight, rather stout, expanded at middle; terminal 0.15 sclerotized, tip blunt. Ostium situated at 0.45 of sterigma, round, anterior and lateral margins reinforced. Sternum VII rectangular, 1.6 $\times$ wider than high; posterior margin medially slightly concave. Apophyses anteriores as long as apophyses posteriores.

Distribution. Afghanistan, Pakistan, Tajikistan.

Remarks. New to Tajikistan. The genitalia of both sexes (Figs. 5-8) and the habitat of the moth 


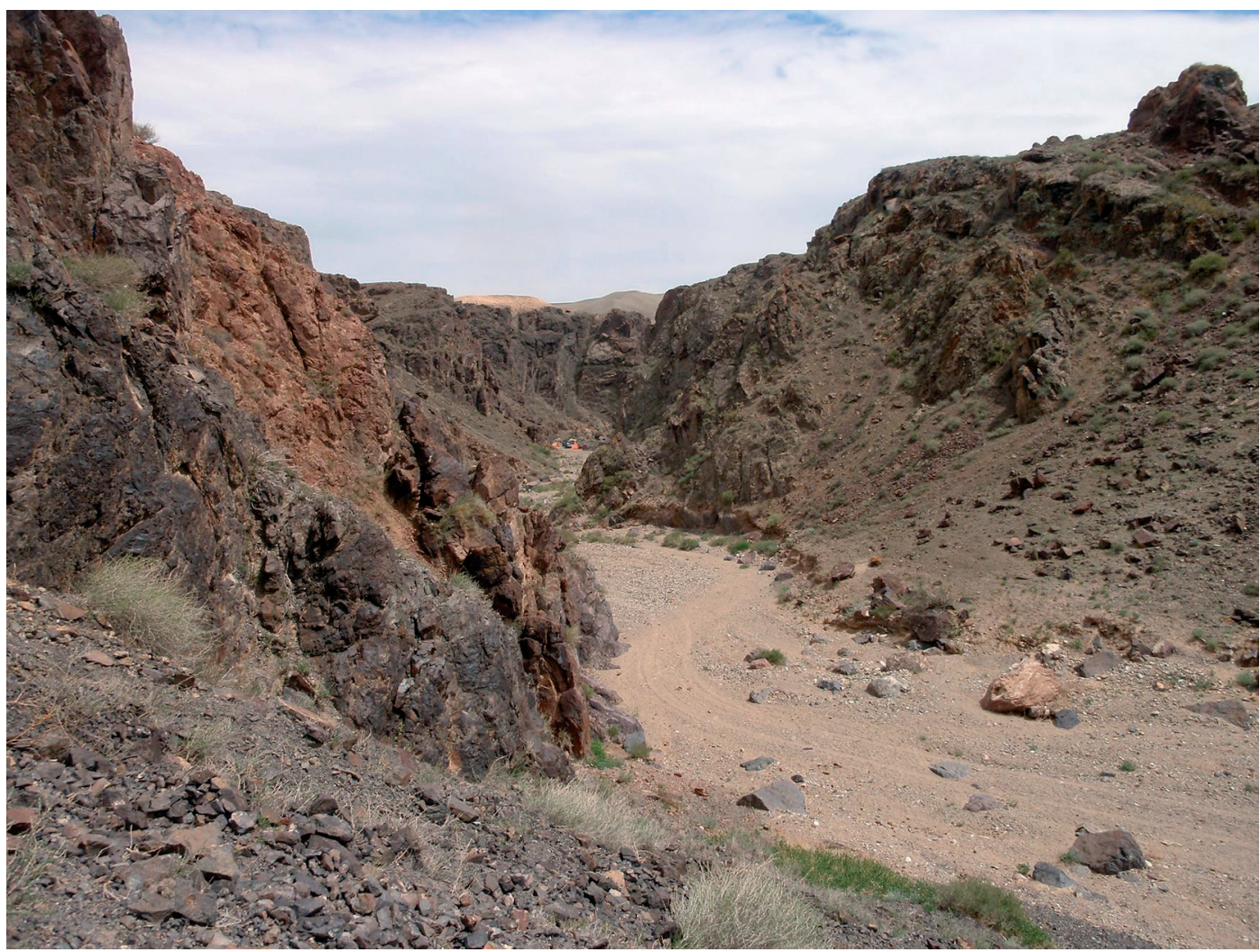

Fig. 4. Habitat of Scythris innae K. Nupponen \& Haverinen, sp. n.: rocky steppe slopes by Charyn Canyon (1,220 m a.s.I.), SE Kazakhstan. (Photo: K. Nupponen).

(Fig. 9) are illustrated. The hitherto unknown female genitalia of the species are described above. The female genitalia resemble those of $S$. karvoneni Nupponen, 2010, but differ by the sterigma with larger terminal sclerotization and less defined ostium.

Falkovitshella hypolepta (Falkovitsh, 1972)

Material. Kazakhstan, 43 46' 43" N 79० 55' 16" E, 515 m, desert near Rakhat Kuduk by Ketmen Mts., 4 ふ઼ 1 ๆ 4.VI.2014, K. Nupponen \& R. Haverinen leg. Genitalia slide: K. Nupponen prep. no. 3/24.VIII.2014 (). Three genitalia preparations preserved in glycerol. DNA samples (Lepid. Phyl., green label): KN00490, KN00491.

Female genitalia (Figs. 10-11). Sterigma long and narrow, club-shaped with posterior hood, anteriorly widened and slightly incised. Ostium small and round, situated at 0.8 of sterigma. Sternum VII subrectangular, $1.4 \times$ wider than high; posterior margin medially slightly concave, anterior margin widely incurved; sublaterally pair of weakly sclerotized oval patches. Apophyses anteriores $0.9 \times$ length of apophyses posteriores.

Distribution. Kazakhstan, Uzbekistan.

Remarks. New to Kazakhstan. The external appearance of the moth is illustrated for the first time (Fig. 12), as well as the habitat (Fig. 13). The hitherto unknown female genitalia of the species are illustrated and described above.

Scythris niemineni Nupponen, 2014

Material. Tajikistan, W Pamir Mts., $38^{\circ} 18^{\prime} 26^{\prime \prime}$ N 72 $28^{\circ} 38^{\prime \prime}$ E, 2,770 m, Murghab River Valley,

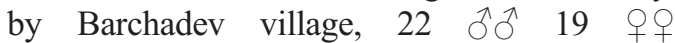
19.VII.2013, K. Nupponen \& R. Haverinen leg.; Tajikistan, W Pamir Mts., $38^{\circ} 18^{\prime} 34^{\prime \prime} \mathrm{N} 72^{\circ} 28^{\prime}$ 36" E, 2,650 m, Murghab River Valley, Barchadev village, 4 ふぇ 5 우 20.VII.2013, K. Nupponen \& M. Rantala leg.; Tajikistan, W Pamir Mts., 3700’ 55”N 72 34’32” E, 2,810 m, 


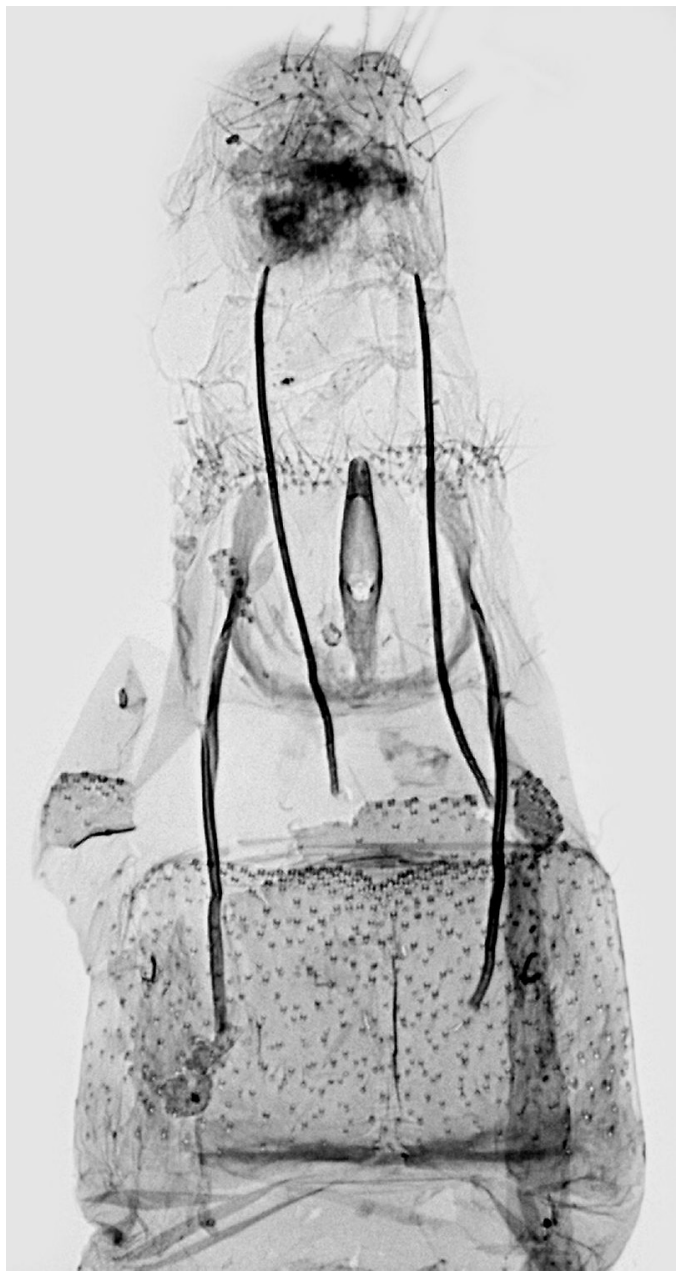

Fig. 5. Female genitalia of Falkovitshella hindukushi Passerin d'Entrèves \& Roggero, 2013 (Tajikistan; Genitalia slide: 1/6.I.2014 KN).

Pyanj/Pamir River, by Zugvand village, $1 \hat{\sigma}$ 25.VII.2013, K. Nupponen \& R. Haverinen leg. Genitalia slides: K. Nupponen prep. no. 2/4.I.2014 (す), 3/6.I.2014 (す), 2/6.I.2014 (†).

Female genitalia (Figs. 14-15). Sterigma narrow and elongated, subtriangular, broadest at 0.25 from base, tip blunt; margins sclerotized. Sternum VII subtrapezoid; posterior margin slightly elongated and medially incised, with weakly sclerotized median bump. Anterior margin of segment VII sclerotized. Apophyses anteriores as long as apophyses posteriores.

Distribution. Kazakhstan, Tajikistan.

Remarks. New to Tajikistan. The hitherto unknown female genitalia of the species are illus-

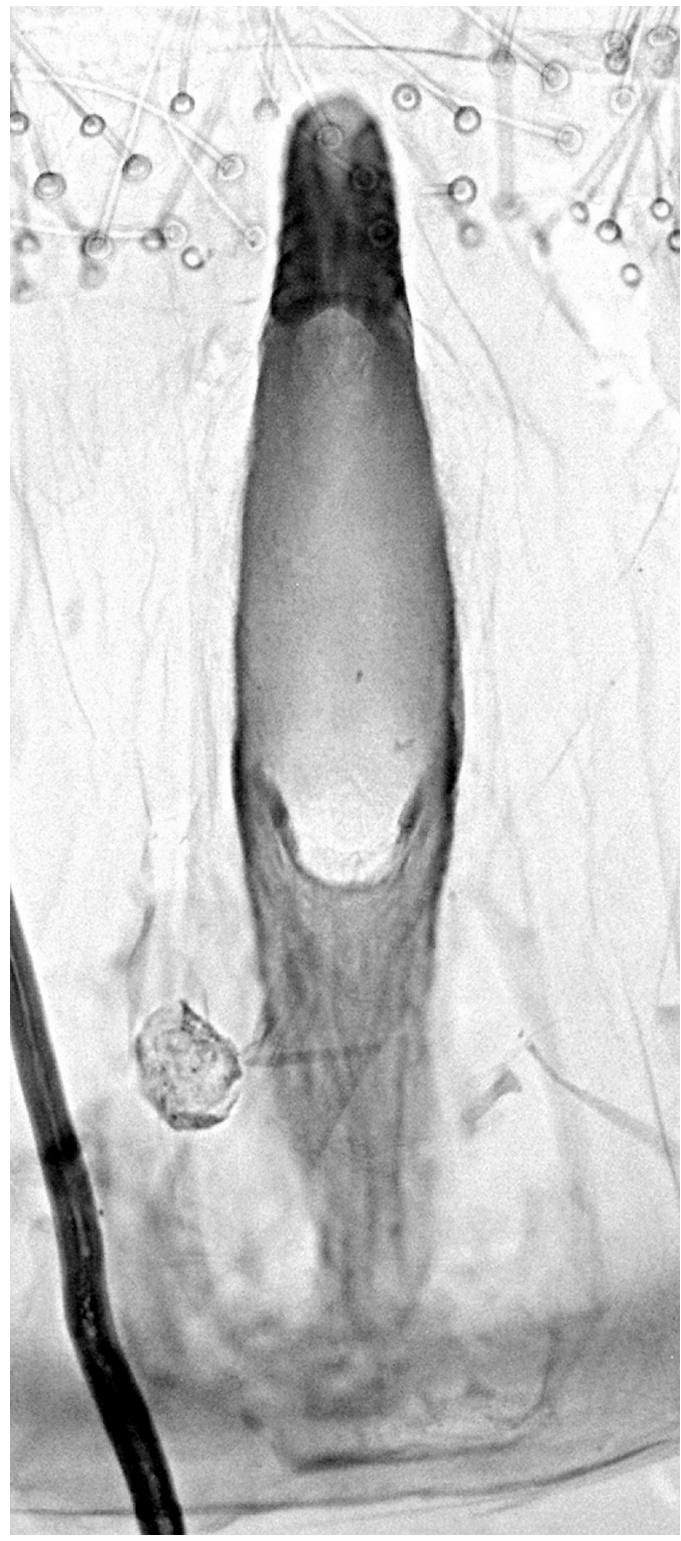

Fig. 6. Sterigma of Falkovitshella hindukushi Passerin d'Entrèves \& Roggero, 2013 (Tajikistan; Genitalia slide: 1/6.I.2014 KN).

trated and described above. The female genitalia of $S$. niemineni are very similar to those of $S$. fissurella Bengtsson, 1996 and S. nivicolor Meyrick, 1916, but differ by the sterigma being broadest at 0.25 (not at base) and sclerotized only at margins. Two females reported from Russia (Astrakhan district) and W Kazakhstan as $S$. fissurella (Nupponen 2007, 2014) refer to $S$. niemineni. The specimens from Tajikistan are 


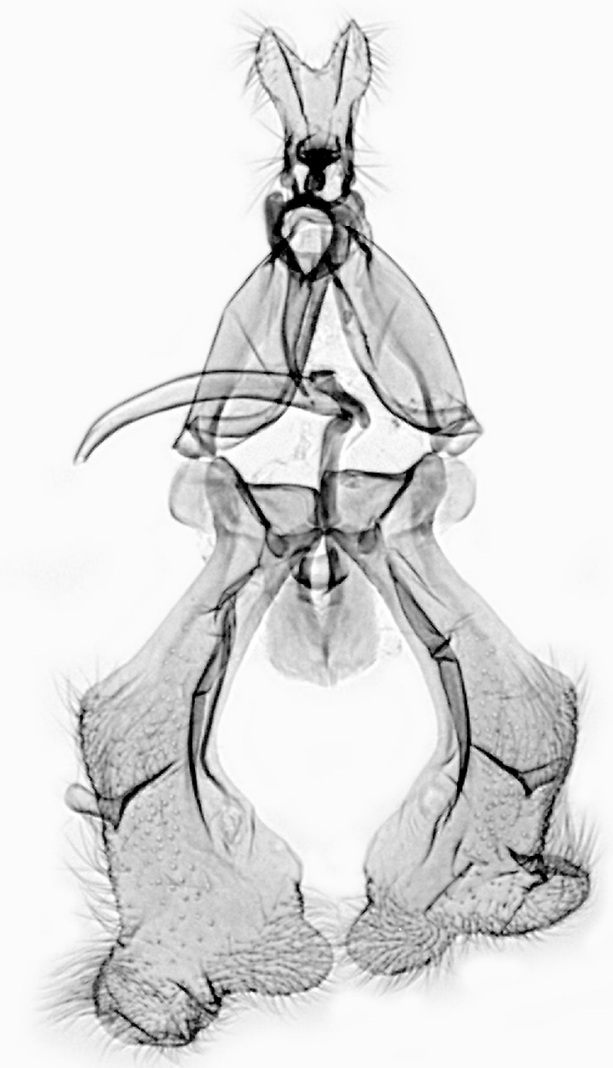

Fig. 7. Male genitalia of Falkovitshella hindukushi Passerin d'Entrèves \& Roggero, 2013 (Tajikistan; Genitalia slide: 1/4.I.2014 KN).

larger in size (wingspan 14-18 $\mathrm{mm}$; in W Kazakhstan 12-14 mm) and darker than specimens from lowlands (Fig. 16). There are differences in the male genitalia between western and eastern populations: in specimens from the Pamirs, the shorter branch of the phallus is broader, ventral extension of the right valva is longer, and the uncus is distally more round. However, such minor individual variation exists also within the Pamir population. On the basis of the DNA barcodes, specimens from the Pamirs are identical to each other $(\mathrm{n}=3)$, and differ by the minimum distance of $1.71 \%$ from the Kazakhstani specimens $(n=3)$. The difference in the barcodes and the genitalia may be explained by the long geographical distance between the isolated populations, and can be seen as representing intraspecific variation. There is also minor variation in the barcodes of the Kazakhstani specimens $(0.15 \%)$. A closely related $S$. fissurella differs by barcode gap of $4.51 \%$ from $S$. niemineni from West Kazakhstan and 5.06\% from the Pamirian specimens. We consider the taxa from the Pamir Mountains and West Kazakhstan to be conspecific.

\section{Annotated list of faunistic records}

The species are listed alphabetically in generic and specific order. The known distribution of each species is given.

Bactrianoscythris fenestratella Nupponen, 2011 Material. Tajikistan, W Pamir Mts., $38^{\circ} 18^{\prime} 34^{\prime \prime N}$ $72^{\circ} 28^{\prime} 36^{\prime \prime}$ E, 2,650 m, Murghab River Valley,

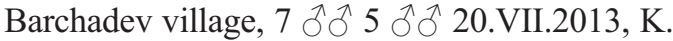
Nupponen \& M. Rantala leg.; Tajikistan, W Pamir Mts., 36 55' 22”'N 71 30'02”'E, 2,600 m, Pyanj River, by Avdj village, 1 ð 26.VII.2013, K. Nupponen \& R. Haverinen leg.; Tajikistan, W Pamir Mts., $37^{\circ} 28^{\prime} 40$ "N $71^{\circ}$ 35' 55” E, 2,300 m, Khorog town, Botanical Garden, 1 त 27.VII.2013, K. Nupponen \& R. Haverinen leg.;

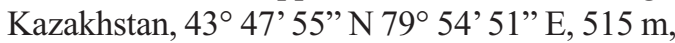
Rakhat Kuduk by Ili River shore, tugai forest, 2

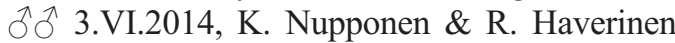
leg. One genitalia preparation preserved in glycerol. DNA sample (Lepid. Phyl., green label): KN00699.

Distribution. Kazakhstan, Kyrgyzstan, Tajikistan.

Remarks. Bactrianoscythris fenestratella was previously known only from the type locality in the Naryn Valley, Kyrgyzstan. New to Kazakhstan and Tajikistan.

Falkovitshella asthena (Falkovitsh, 1972)

Material. Kazakhstan, 43 37' 52" N 79' 55'50" E, 650 m, Rakhat Kuduk by Ketmen Mts., 10 ఓ઼ 9 우 0 2.VI.2014, K. Nupponen \& R. Haverinen leg.; Kazakhstan, 43 46’ 43” N 79 55' 16” E, 515 m, desert near Rakhat Kuduk by Ketmen

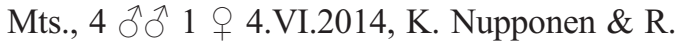
Haverinen leg. 12 genitalia preparations preserved in glycerol.

Distribution. Kazakhstan, Turkmenistan, Uzbekistan.

Falkovitshella physalis (Falkovitsh, 1972)

Material. Kazakhstan, $43^{\circ} 46^{\prime} 43^{\prime \prime}$ N 79 55' 16" 


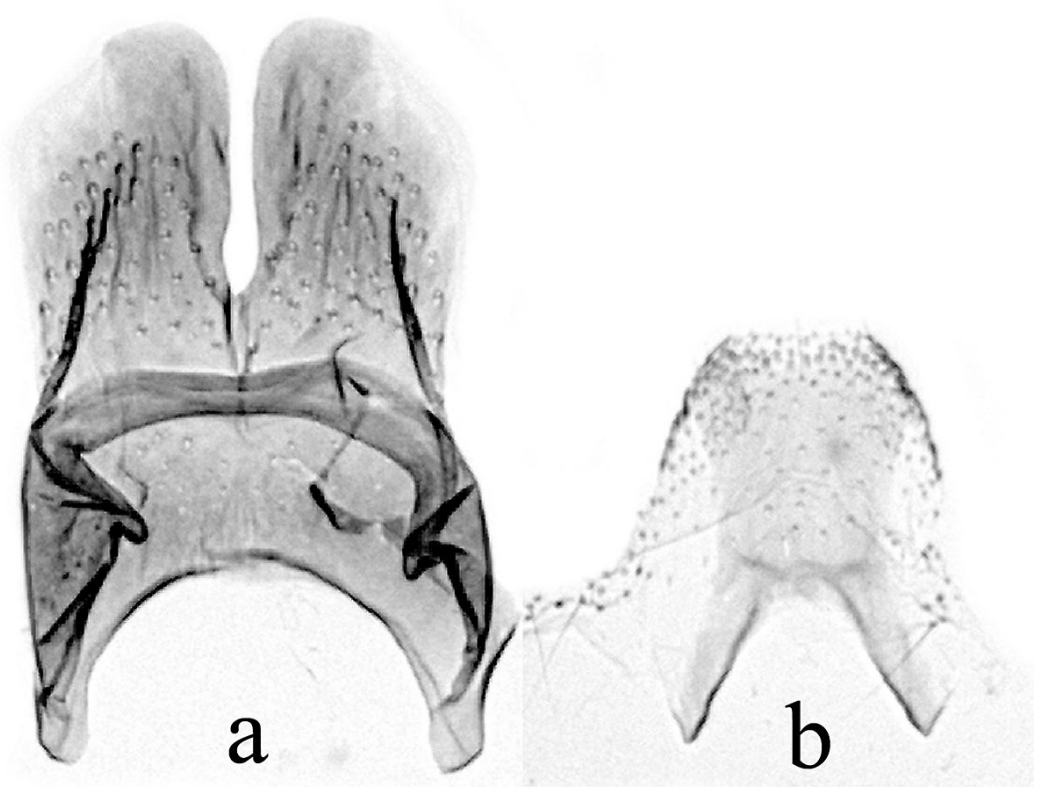

Fig. 8. Abdominal segment VIII of Falkovitshella hindukushi Passerin d'Entrèves \& Roggero, 2013. - a. Sternum. - b. Tergum. (Tajikistan; Genitalia slide: 1/4.I.2014 KN).
E, 515 m, desert near Rakhat Kuduk by Ketmen

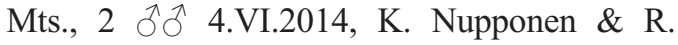
Haverinen leg. One genitalia preparation preserved in glycerol. DNA samples (Lepid. Phyl., green label): KN00492, KN00493.

Distribution. Kazakhstan, Mongolia, Uzbekistan.

Remark. New to Kazakhstan.

Scythris bagdadiella Amsel, 1949

Material. Tajikistan, W Pamir Mts., 38 06' 59" N 70²6'40” E, 1,180 m, Pyanj River, by Zigar village, 1 ^ 1 \% 30.VII.2013, K. Nupponen \& R. Haverinen leg.; Tajikistan, $37^{\circ} 18.100^{\prime} \mathrm{N} 68^{\circ} 23$. 146' E, 312 m, Palvon Tugai, 9 쉬 3 우 1.V.2014, 2 ठิ సે 2.V.2014, T. Nupponen \& R. Haverinen leg.; Tajikistan, $37^{\circ} 16.332^{\prime} \mathrm{N} 68^{\circ} 20$. 465’ E, 317 m, Palvon Tugai, 7 ふふર 1 4.V.2014, T. Nupponen \& R. Haverinen leg.; Tajikistan, $37^{\circ}$ 19.961 ' $\mathrm{N} 68^{\circ} 27.475$ ' E, $324 \mathrm{~m}$, Tigrovaya Balka, 1 ते 3.V.2014, T. Nupponen \& R. Haverinen leg.; Kazakhstan, $43^{\circ} 37^{\prime} 52^{\prime \prime}$ N $79^{\circ}$ 55' 50" E, 650 m, Rakhat Kuduk by Ketmen Mts., 12 ฝิฮี 10 우 2.VI.2014, K. Nupponen \& R. Haverinen leg.; Kazakhstan, 43 $47^{\prime} 55^{\prime}$ N $79^{\circ}$ 54' 51" E, 515 m, Rakhat Kuduk by Ili River

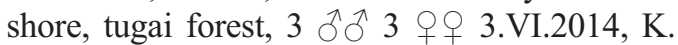
Nupponen \& R. Haverinen leg. Genitalia slide: K. Nupponen prep. no. 3/4.I.2014 (ð̋). DNA sample (Lepid. Phyl., green label): KN00487.
Distribution. Afghanistan, Algeria, Iraq, Kazakhstan, Russia (S Ural), Tajikistan, Turkey, Uzbekistan.

Remark. New to Tajikistan.

Scythris brandti Passerin d'Entrèves \& Roggero, 2008

Material. Tajikistan, $37^{\circ} 19.961^{\prime} \mathrm{N} 68^{\circ} 27.475^{\prime}$

E, 324 m, Tigrovaya Balka, 1 đ 3.V.2014, T. Nupponen \& R. Haverinen leg.

Distribution. N Afghanistan, Kazakhstan, Tajikistan.

Remark. New to Tajikistan.

Scythris caballoides Nupponen, 2009

Material. Kazakhstan, 47० 49' 29" N 59॰ 46' 49" E, 195 m, Bolshie Barsuki sands, Chelkar settlement 13 km E, 6 ठึ đ̂ 1.V.2014, K. Nupponen leg. DNA samples (Lepid. Phyl., green label): KN00498, KN00499.

Distribution. Kazakhstan, Uzbekistan.

Scythris canescens (Staudinger, 1880)

Material. Tajikistan, W Pamir Mts., $38^{\circ} 18^{\prime} 26^{\prime \prime}$ N 72 28 ' 38' E, 2,770 m, Murghab River Valley, by Barchadev village, 2 ふぇ 5 우 19.VII.2013, K. Nupponen \& R. Haverinen leg.; Tajikistan, W Pamir Mts., 38 18 ' 34” N 72 28’36” E, 2,650 m, Murghab River Valley, Barchadev village, 1 त 3 우 ㅇ 20.VII.2013, K. Nupponen \& M. Rantala 


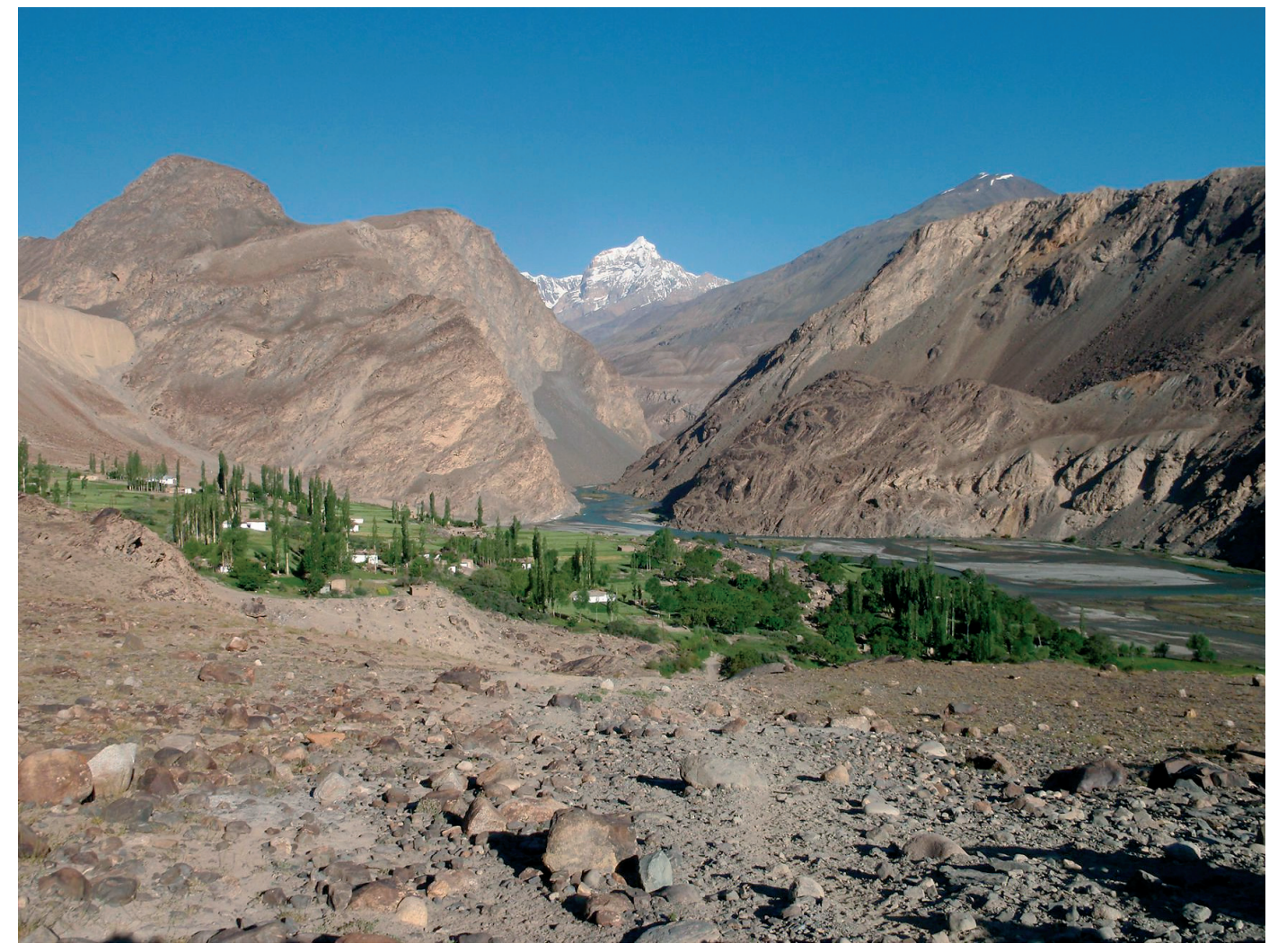

Fig. 9. Habitat of Falkovitshella hindukushi Passerin d'Entrèves \& Roggero, 2013 and Scythris niemineni Nupponen, 2014: mountain steppes by Murghab River Valley, W Pamir Mts. (2,770 m a.s.I.), Tajikistan. (Photo: K. Nupponen).

leg.; Tajikistan, W Pamir Mts., $36^{\circ} 55^{\prime} 22^{\prime \prime} \mathrm{N} 71^{\circ}$ 30'02' E, 2,600 m, Pyanj River, by Avdj village, 10 ऽิ 8 우 26.VII.2013, K. Nupponen \& R. Haverinen leg.; Tajikistan, $37^{\circ} 18.100^{\prime} \mathrm{N} 68^{\circ}$ 23.146’ E, 312 m, Palvon Tugai, 1 त 2 우 1.V.2014, 1 ○ 2.V.2014, T. Nupponen \& R. Haverinen leg.; Tajikistan, $37^{\circ} 16.332^{\prime} \mathrm{N} 68^{\circ}$ 20.465' E, 317 m, Palvon Tugai, 1 đ̊ 4.V.2014, T. Nupponen \& R. Haverinen leg. Genitalia slides: K. Nupponen prep. no. 3/6.I.2014 (ð), 2/6.I.2014 (†). One genitalia preparation preserved in glycerol.

Distribution. Afghanistan, Algeria, Iran, Libya, Morocco, Pakistan, Syria, Tajikistan, Tunisia, Turkey, Uzbekistan.

\section{Scythris capitalis (Erschoff, 1874)}

Material. Tajikistan, W Pamir mts., $38^{\circ} 37^{\prime} 31^{\prime \prime} \mathrm{N}$ 70 45' 29' E, 3,000-3,200 m, Devlokh Valley,

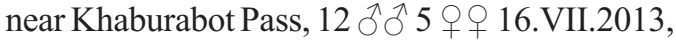
3 ठૈす 3 우 17.VII.2013, K. Nupponen leg.
Distribution. Afghanistan, Iran, Kazakhstan, Kyrgyzstan, Turkey, Turkmenistan, Tajikistan, Uzbekistan.

Scythris clavella (Zeller, 1855)

Material. Kazakhstan, 432 23' 28" N $77^{\circ} 36^{\prime} 45^{\prime}$ " E, 1,050 m, Trans-Ili Alatau Mts., Turgen River org, steppe slopes by Turgen village, $1 \lesssim$ 6.VI.2014, K. Nupponen leg.

Distribution. C and S Europe east to SW Altai; N, W and SE Kazakhstan, Kyrgyzstan.

Scythris dicroa Falkovitsh, 1972

Material. Kazakhstan, $43^{\circ} 37^{\prime} 52^{\prime \prime}$ N $79^{\circ} 55^{\prime}$ '50" E, 650 m, Rakhat Kuduk by Ketmen Mts., 7 § 3 우 2.VI.2014, K. Nupponen \& R. Haverinen leg.; Kazakhstan, 43 46’ 43" N 79॰ 55' 16" E, 515 m, desert near Rakhat Kuduk by Ketmen Mts., 1 đ 4.VI.2014, K. Nupponen \& R. Haverinen leg. Four genitalia preparations preserved in glycerol.

Distribution. Kazakhstan, Uzbekistan. 


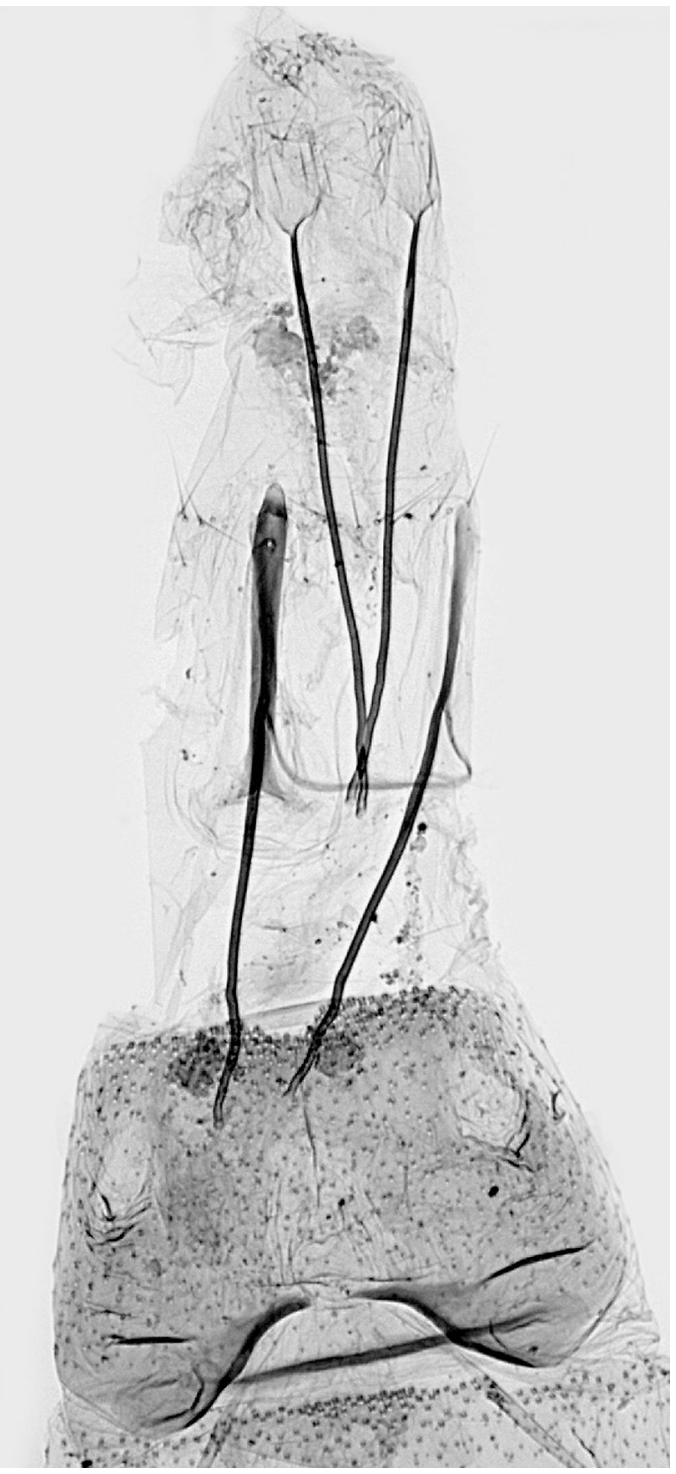

Fig. 10. Female genitalia of Falkovitshella hypolepta (Falkovitsh, 1972) (SE Kazakhstan; Genitalia slide: 3/24.VIII.2014 KN).

Scythris haloxylella Falkovitsh, 1969

Material. Kazakhstan, 43 46' 43" N 79॰ 55' 16" E, 515 m, desert near Rakhat Kuduk by Ketmen Mts., 9 ふ઼ 1 ๆ 4.VI.2014, K. Nupponen \& R. Haverinen leg. DNA samples (Lepid. Phyl., green label): KN00495, KN00496, KN00497.

Distribution. Kazakhstan, Turkmenistan, Uzbekistan.

Scythris karvoneni Nupponen, 2010

Material. Kazakhstan, $43^{\circ} 37^{\prime} 52^{\prime \prime}$ N $79^{\circ} 55^{\prime} 50^{\prime}$ "

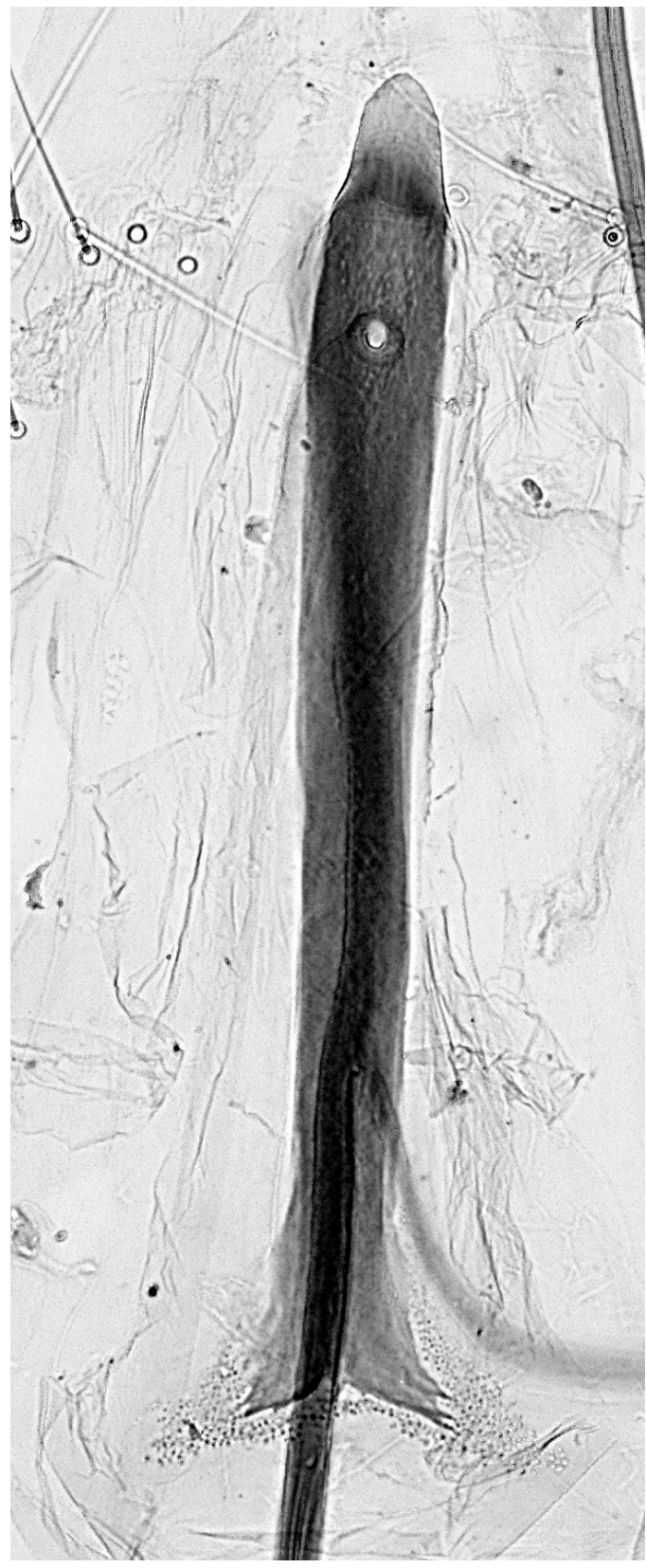

Fig. 11. Sterigma of Falkovitshella hypolepta (Falkovitsh, 1972) (SE Kazakhstan; Genitalia slide: 3/24.VIII.2014 KN).

E, 650 m, Rakhat Kuduk by Ketmen Mts., $6 \curvearrowright ぇ 1$ + 2.VI.2014, K. Nupponen \& R. Haverinen leg. Four genitalia preparations preserved in glycerol. Distribution. Kazakhstan, Uzbekistan. 
Fig. 12. Adult male of Falkovitshella hypolepta (Falkovitsh, 1972) (SE Kazakhstan).
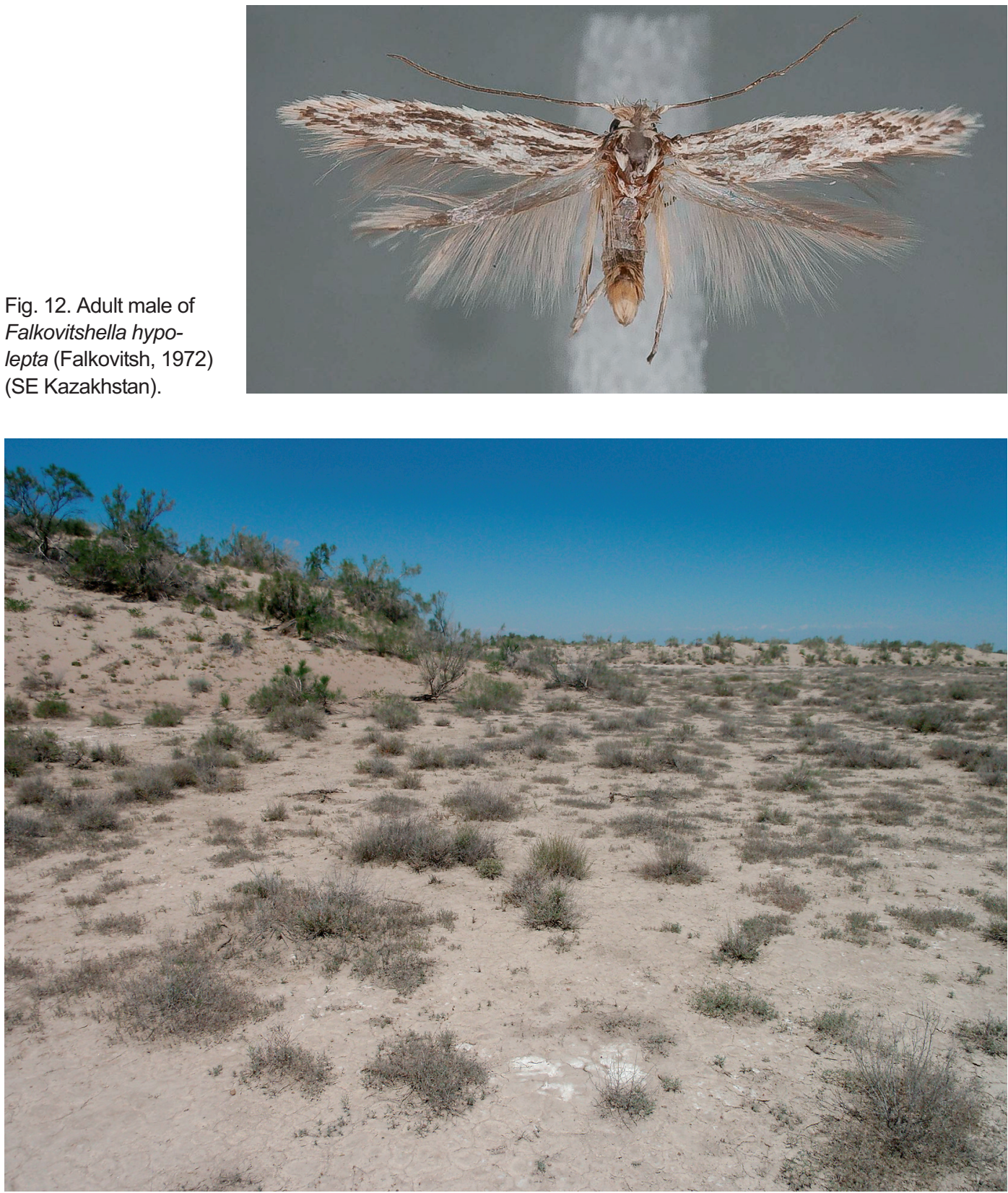

Fig. 13. Habitat of Falkovitshella hypolepta (Falkovitsh, 1972), Scythris kaszabi Passerin d'Entrèves \& Roggero, 2006 and Scythris stalagmitella Nupponen, 2010: desert and sand dunes by Rakhat Kuduk in the lli River Basin (515 m a.s.I.), SE Kazakhstan. (Photo: K. Nupponen).

Scythris kaszabi Passerin d'Entrèves \& Roggero, 2006

Material. Kazakhstan, $43^{\circ} 46^{\prime} 43^{\prime \prime}$ N $79^{\circ} 55^{\prime} 16^{\prime \prime}$ E, 515 m, desert near Rakhat Kuduk by Ketmen

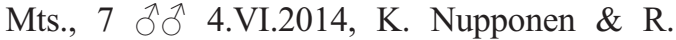
Haverinen leg. Genitalia slide: K. Nupponen prep. no. 2/29.XI.2014. DNA sample (Lepid. Phyl., green label): KN00489.

Distribution. SE Kazakhstan, Mongolia.

Remarks. New to Kazakhstan. The external appearance of the moth is illustrated for the first time (Fig. 17), as well as the habitat (Fig. 13). 


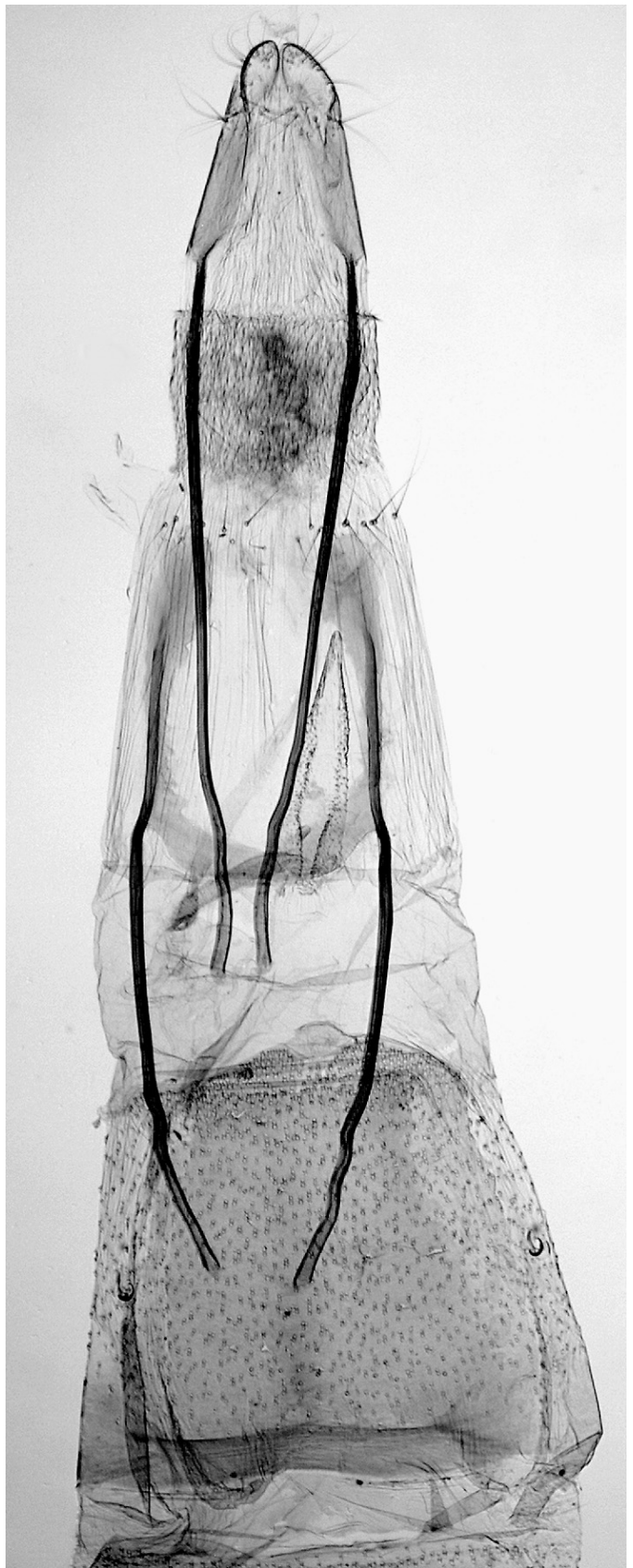

Fig. 14. Female genitalia of Scythris niemineni Nupponen, 2014 (Lower Volga, Russia; Genitalia slide: 1/14.X.2006 KN).

Scythris limbella (Fabricius, 1775)

Material. Kazakhstan, 43 26' 51" N 78 40' 31" E, 1,130 m, Kokpek village, 1 ○े 5.VI.2014, K. Nupponen \& R. Haverinen leg.

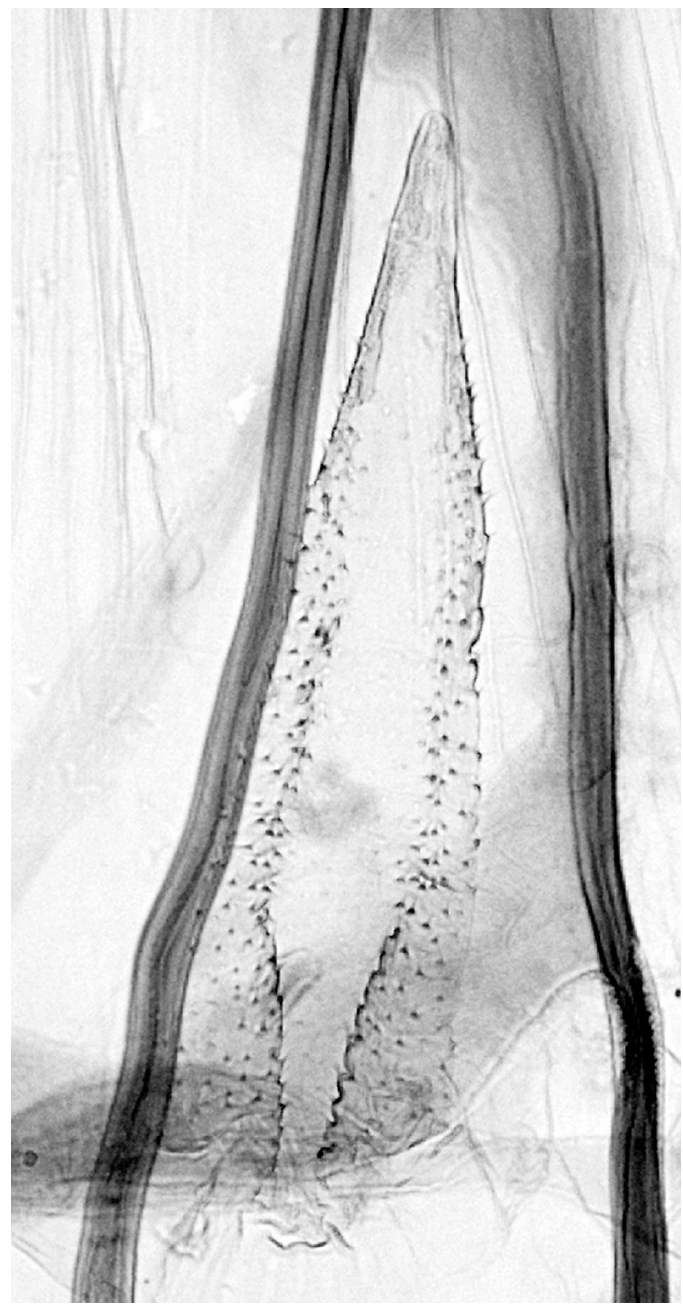

Fig. 15. Sterigma of Scythris niemineni Nupponen, 2014 (Lower Volga, Russia; Genitalia slide: 1/14.X.2006 KN).

Distribution. W Palaearctic eastward to Altai and C Asia, E Nearctic.

Scythris monochreella (Ragonot, 1896)

Material. Tajikistan, $37^{\circ} 14.871^{\prime} \mathrm{N} 69^{\circ} 14.125^{\prime}$ E, 525 m, Pyanj River, 3 of 5.V.2014, T. Nupponen \& R. Haverinen leg. Genitalia slide: K. Nupponen prep. no. 4/29.XI.2014.

Distribution. Egypt, India, Iraq, Iran, Israel, Lebanon, Syria, Tajikistan, Turkey, UAE.

Remarks. New to Tajikistan.

Scythris obliqua Falkovitsh, 1969

Material. Kazakhstan, $43^{\circ} 46^{\prime} 43^{\prime \prime}$ N $79^{\circ} 55^{\prime}$ '16" E, 515 m, desert near Rakhat Kuduk by Ketmen 


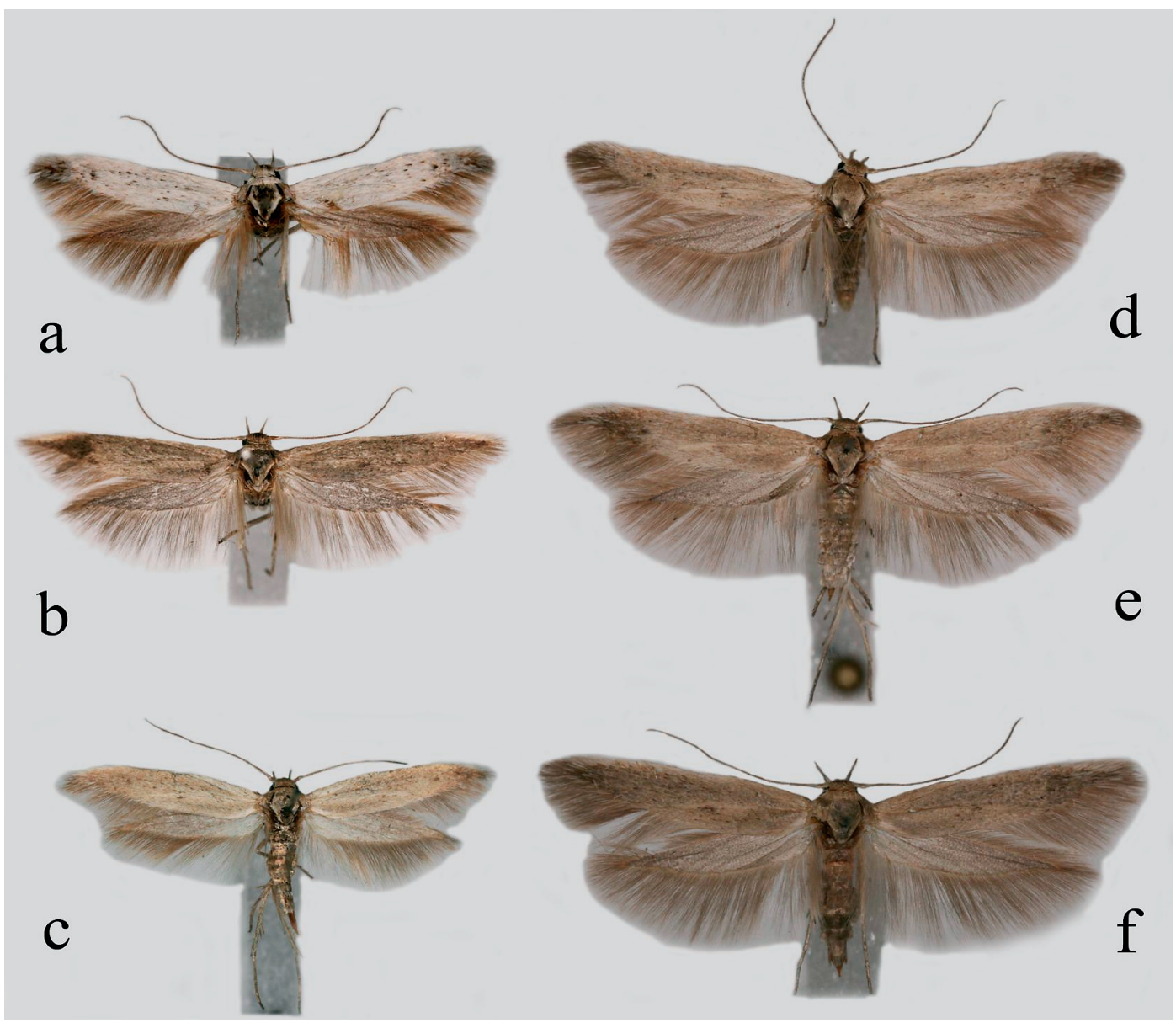

Fig. 16. Adults of Scythris niemineni Nupponen, 2014. - a. W Kazakhstan (male, holotype). - b. SW Kazakhstan, Mangystau (female). - c. Russia, Lower Volga basin (female). - d-f. W Pamir Mts., Tajikistan (d. male. e-f. females).

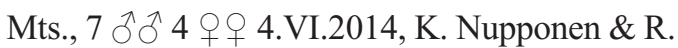
Haverinen leg.

Distribution. Kazakhstan, Mongolia, Uzbekistan.

Scythris parafluxilis Passerin d'Entrèves \& Roggero, 2007

Material. Kazakhstan, $43^{\circ} 32^{\prime}$ '52"N 67³0'09" E, $170 \mathrm{~m}$, Syr-Darya River, tugai forest, Talap station $13 \mathrm{~km} \mathrm{SW}, 1$ ऽ 19.IV.2014, K. Nupponen leg.; Kazakhstan, $47^{\circ} 26^{\prime} 23^{\prime \prime} \mathrm{N} 60^{\circ} 49^{\prime} 04^{\prime \prime} \mathrm{E}$, $150 \mathrm{~m}$, Malye Barsuki sands, Karachokat village 5 km NW, 1 ते 30.IV.2014, K. Nupponen leg.; Kazakhstan, 47 49'29” N 59॰ 46’ 49” E, 195 m, Bolshie Barsuki sands, Chelkar settlement $13 \mathrm{~km}$ E, 1 § 1.V.2014, K. Nupponen leg.; Kazakhstan, $43^{\circ} 46^{\prime} 43^{\prime \prime} \mathrm{N} 79^{\circ} 55^{\prime} 16^{\prime \prime} \mathrm{E}, 515 \mathrm{~m}$, desert near
Rakhat Kuduk by Ketmen Mts., 11 ○ึ 2 우 4.VI.2014, K. Nupponen \& R. Haverinen leg. Genitalia slide: K. Nupponen prep. no. 2/24.VIII. 2014 ( + ). Three genitalia preparations preserved in glycerol. DNA samples (Lepid. Phyl., green label): KN00500, KN00501, KN00502.

Distribution. Kazakhstan, Mongolia.

Remarks. The description of $S$. parafluxilis is based on two females from Mongolia, and the status of a few males from Kazakhstan considered as S. parafluxilis has been doubtful (see Nupponen 2011, 2012). A series of specimens, including both males and females, of the Kazakhstani taxon was collected in early June, 2014. The dissection revealed that there are small differences in the female genitalia of the Kazakhstani taxon compared with those of the type specimens: the 


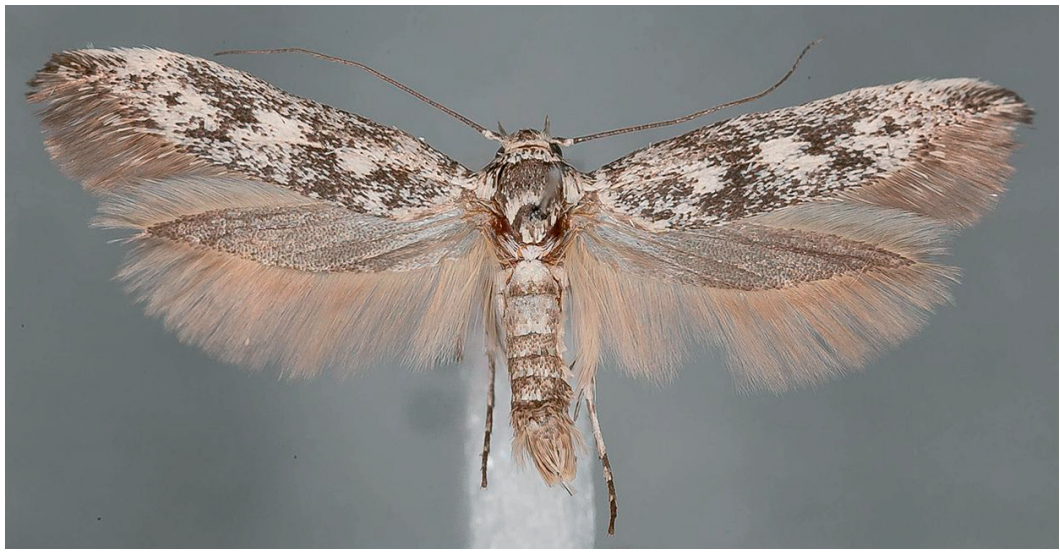

Fig. 17. Adult male of Scythris kaszabi Passerin d'Entrèves \& Roggero, 2006 (SE Kazakhstan). sterigma is longer and narrower, and medial notch of segment VII is broader. The specimens from Kazakhstan are also smaller in size, as the wing span varies between $11.5-14 \mathrm{~mm}(16 \mathrm{~mm}$ in the holotype). Further material of $S$. parafluxilis from Mongolia is needed, until the final decision of conspecifity of the Mongolian and Kazakhstani taxa can be made. Scythris parafluxilis belongs to the caroxylella complex in the pascuella species-group, comprising at least five described species (Nupponen 2010). The barcode gaps between the species are as follows: caroxylellafluxilis $4.53 \%$; caroxylella-rotundella $4.34 \%$; caroxylella-cramella 4.39\%; caroxylella-parafluxilis $4.93 \%$; fluxilis-rotundella $3.51 \%$; fluxilis-cramella $6.17 \%$; fluxilis-parafluxilis $4.54 \%$; rotundella-cramella $5.44 \%$; rotundellaparafluxilis $\quad 2.24 \%$; cramella-parafluxilis $5.99 \%$.

\section{Scythris rotundella Nupponen, 2010}

Material. Kazakhstan, $43^{\circ} 37^{\prime} 52^{\prime \prime}$ N $79^{\circ} 55^{\prime}$ '50" E, 650 m, Rakhat Kuduk by Ketmen Mts., 1 ภ 2 우 2.VI.2014, K. Nupponen \& R. Haverinen leg.; Genitalia slide: K. Nupponen prep. no. 3/29.XI.2014 (ㅇ). One genitalia preparation preserved in glycerol.

Distribution. Kazakhstan, Uzbekistan.

Scythris semifascia Nupponen, 2010

Material. Tajikistan, $37^{\circ} 16.332^{\prime}$ N $68^{\circ} 20.465^{\prime}$

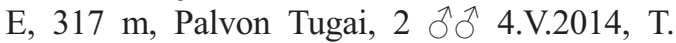
Nupponen \& R. Haverinen leg.

Distribution. Kazakhstan, Uzbekistan, Tajikistan.
Remarks. The species is new to Tajikistan. It inhabits tugai forests by large Central Asian rivers. The species was previously known only in the Syr-Darya Valley, but the present record endorses its occurrence in the Amu-Darya Valley too. The majority of Turanian tugai forests have already been destructed by agricultural influence and timber cutting, and therefore $S$. semifascia should be considered a vulnerable species.

Scythris stalagmitella Nupponen, 2010

Material. Kazakhstan, 43 47' 55" N 79 54' 51" E, 515 m, Rakhat Kuduk by Ili River shore, tugai forest, 1 त 3.VI.2014, K. Nupponen \& R. Haverinen leg.; Kazakhstan, $43^{\circ} 46^{\prime} 43^{\prime \prime} \mathrm{N} 79^{\circ}$ 55' 16" E, 515 m, desert near Rakhat Kuduk by Ketmen Mts., 1 o 4.VI.2014, K. Nupponen \& R. Haverinen leg. One genitalia preparation preserved in glycerol. DNA sample (Lepid. Phyl., green label): KN00503.

Distribution. W \& SE Kazakhstan, Russia (S Ural), Turkey.

Remark. The present record extends the known distribution range of $S$. stalagmitella about $1,700 \mathrm{~km}$ to the east.

Scythris syrdaryae Nupponen, 2014

Material. Kazakhstan, $43^{\circ} 37^{\prime} 52^{\prime \prime}$ N $79^{\circ} 55^{\prime}$ '50" E, 650 m, Rakhat Kuduk by Ketmen Mts., 2 ○े 2.VI.2014, K. Nupponen \& R. Haverinen leg. Genitalia slide: K. Nupponen prep. no. 1/29.XI.2014.

Distribution. S \& SE Kazakhstan. 
Scythris tugaiensis Nupponen, 2009

Material. Kazakhstan, $43^{\circ} 47^{\prime} 55^{\prime \prime}$ N 79 $54^{\prime}$ '51" E, $515 \mathrm{~m}$, Rakhat Kuduk by Ili River shore, tugai forest, 1 ○े 1 \& 3.VI.2014, K. Nupponen \& R. Haverinen leg.; Tajikistan, $37^{\circ} 19.961^{\prime} \mathrm{N} 68^{\circ}$ 27.475' E, 324 m, Tigrovaya Balka, 3.V.2014, 1 đ, 1 q, T. Nupponen \& R. Haverinen leg.; Tajikistan, $38^{\circ} 02.392^{\prime} \mathrm{N} 70^{\circ} 12.508^{\prime} \mathrm{E}, 1,312 \mathrm{~m}$, Dashtijum, 1 oे 6.V.2014, T. Nupponen \& R. Haverinen leg. One genitalia preparation preserved in glycerol. DNA sample (Lepid. Phyl., green label): KN00507.

Distribution. Kazakhstan, Tajikistan, Uzbekistan.

Remarks. New to Tajikistan. Scythris tugaiensis inhabits tugai forests by large Central Asian rivers. The species was previously known only in the Syr-Darya Valley, but the present records endorse its occurrence also in the Amu-Darya and Ili Valleys. Specimens from Tajikistan are externally much darker than those from Uzbekistan and Kazakhstan. The majority of Turanian tugai forests have already been destructed by agricultural influence and timber cutting. Due to the decreasing amount and quality as well as fragmentation of its habitat, S. tugaiensis should be considered a vulnerable species.

\section{Discussion}

Similar to many other areas in the Palaearctic region, the scythridid fauna of Central Asia can be considered moderately poorly known. Old information on distribution ranges of many species is based on single specimens collected occasionally among other insect materials. As many scythridids are difficult to observe in the field, one must focus on them to have good results. Unfortunately, Scythrididae and microlepidoptera in general are less attractive groups for most collectors, and due to that our knowledge of those species is increasing very slowly.

The scythridid fauna of the Ili River basin is very interesting, comprising elements of both Mongolia and Central Asian deserts. Our records from two short expeditions in 2003 and 2014 indicate that the diversity of Scythrididae is high in the region, and most probably many further species remain to be discovered there.

The scythridid fauna in high mountain ranges is scarce. Despite favourable weather and apparently suitable habitats, we did not record any scythridid specimens at the altitude over $3,500 \mathrm{~m}$ a.s.l. in the Pamir Mountains. The few observed species (B. fenestratella, S. hindukushi, S. canescens, S. capitalis, S. niemineni) inhabit steep and obviously warm river valleys. Similar situation also prevails in many other Central Asian mountains, like the Alai, Trans-Alai and Tien-Shan ranges (Nupponen 2011, Nupponen \& Sinev 2011).

The foothills steppes and deserts adjacent to Central Asian Mountains are rich in Scythrididae. The species richness at lowlands appears to be the highest during late May - mid June. However, the spring fauna of Scythrididae in Kazakhstan is very scarce, as we discovered only a single species (S. parafluxilis) in mid-April.

Overgrazing is a serious problem in steppes at all altitudes and particularly in foothills all over Central Asia. The amount of sheep has significantly increased since the USSR collapsed, which has resulted in destruction and fragmentation of large areas of quality habitats during the last 20 years. As most of the scythridid species exclusively inhabit such xerothermic steppes, it is rather difficult to find suitable habitats for collecting. For example, steppes by the Charyn Canyon were in moderately good condition still in 2003 (Nupponen et al. 2005), while in 2014 the majority of them were already more or less destroyed, and the remaining spots of quality habitats are located in inaccessible semi-vertical slopes. Generally, in river valleys and canyons the slopes are often too steep for cattle, and the quality of such localities remains sufficient for moths. Therefore, various species, including scythridids, are most frequently detected by rivers, like most of the specimens collected by us in the Pamirs.

Acknowledgements. The senior author is indebted to Pavel Gorbunov (Ekaterinburg, Russia) for organizing the expeditions to Kazakhstan. We also thank the staff of the Charyn National Park (Kazakhstan) and the National Reserve of the Tigrovaya Balka (Tajikistan) for help to get collecting permits; Pasi Sihvonen (Kirkkonummi, Finland) and Kimmo Silvonen (Espoo, Finland) for their help in processing the photographs; Alexander Ivanov (Ekaterinburg, Russia), Mari Kekkonen (Guelph, Canada), Alikhon Latifi (Dushanbe, Tajikistan), Elena Nupponen (Espoo, Finland), Vladimir Olschwang (Ekaterinburg, Russia), Markus Rantala (Kerava, Finland) and Faunatica 
Oy for various kinds of support and assistance. Bengt Bengtsson (Färjestaden, Sweden) and two anonymous referees improved the manuscript by useful comments.

\section{References}

Nupponen, K. 2007: Notes on the Scythrididae fauna of the Volgo-Ural region and southern Buryatia, with one new synonym and descriptions of six new species (Lepidoptera: Scythrididae). - SHILAP Revista de Lepidopterologia 35(138): 231-249.

Nupponen, K. 2010: Notes on Scythrididae from the Turanian region, with descriptions of six new species (Lepidoptera: Scythrididae). - SHILAP Revista de Lepidopterologia 38(151): 267-285.

Nupponen, K. 2011: Notes on Scythrididae from the Turanian region, with one new synonym and descriptions of seven new species (Lepidoptera: Scythrididae). -
SHILAP Revista de Lepidopterologia 39(155): 301319.

Nupponen, K. 2012: Notes on Scythrididae from southern and western Kazakhstan, with description of Scythris aralensis Nupponen, sp. n. (Lepidoptera: Scythrididae). - SHILAP Revista de Lepidopterologia 40(160): 475-488.

Nupponen, K. 2014: Notes on Scythrididae observed during 2012 in southern and western Kazakhstan, with descriptions of six new species (Lepidoptera: Scythrididae). - SHILAP Revista de Lepidopterologia 42(166): 237-255.

Nupponen, K., Jürivete, U. \& Pototski, A. 2005: Records of scythridids from Southeastern Kazakhstan, with description of five new species (Lepidoptera: Scythrididae). - Entomologica Fennica 16: 65-73.

Nupponen, K. \& Sinev, S. 2011: Three new species of Scythrididae from the northern Tien-Shan Mountains (Lepidoptera: Scythrididae). — Entomologica Fennica 22: 121-128. 